central nervous system, then it seems plausible that the emotional reactivity of the fast-conditioning $\mathrm{C}_{3} \mathrm{H}$ strain is close to an optimal level (in terms of an inverted-U function), so that magnesium pemoline increases activation beyond its optimal level, resulting in a decrement of performance. However, in the ST/bJ strain, magnesium pemoline increases the "emotional reactivity" to a level that is facilitatory for learning and performance in terms of the inverted-U function.

\section{REFERENCES}

BEACH, G., \& KIMBLE, D. P. Activity and responsivity in rats after magnesium pemoline injections. Science, 1967, 151, 698-701.

BOITANO, J. J., \& BOITANO, J. C. Magnesium pemoline: Enhancement of spontaneous motor activity. Psychonomic Science, 1967, 9, 295-296.

CARR AN, A. B., YEUDALL, L. T., \& ROYCE, J. R. Voltage level and skin resistance in avoidance conditioning in inbred strains of mice. Journal of Comparative \& Physiological Psychology, 1964, 58, 427-430.

CHASE, T. C., \& RESCORLA, R. A. The effect of magnesium pemoline on learning an active avoidance-passive avoidance discrimination. Psychonomic Science, 1968, 10, 87-88.

CYERT, L. A., MOYER, K. E., \& CHAPMAN, J. A. Effect of magnesium pemoline on learning and memory of a one-way avoidance response. Psychonomic Science, 1967, 7, 9-10.

FREY, P. W., \& POLIDORA, V. J. Magnesium pemoline: Effect on avoidance conditioning in rats. Science, 1967, 155, 1281-1282.

GUROWITZ, E. M., LUBAR, J. F., AIN, B. R., \&
GROSS, D. A. Disiuption of passive avoidance learning by magnesium pemoline. Psychonomic Science, 1967, 8, 19-20.

KULKARNI, A. S. Magnesium pemoline: Facilitation of instrumental avoidance learning. Psychonomic Science, 1967, 9, 39-40.

McCARROLL, J. E., \& KORBEL, S. F. Magnesium pemoline: Effects on the learning and retention of a conditioned avoidance response by rats. Psychonomic Science, 1968, $11,233-234$.

PLOTNIKOFF, $\quad \mathrm{N}$. Magnesium pemoline: Enhancement of learning and memory of a conditioned avoidance response. Science, 1966, 151, 703-704.

POWELL, B. J., MARTIN, L. K., \& KAMANO, D. K. More on magnesium pemoline: Differential effects of advance and immediate injections on avoidance performance. Psychonomic Science, 1967, 8, 303-304.

ROYCE, J. R. Optimal stimulus parameters in avoidance conditioning of inbred strains of mice. Multivariate Behavioral Research, 1966, 1, 209-217.

ROYCE, J. R., and COVINGTON, M. Genetic differences in the avoidance conditioning of mice. Journal of Comparative \& Physiological Psychology, 1960, 53, 197-200.

THOMPSON, R., \& KNUDSON, G. R. Magnesium pemoline: Facilitation of one way and two way avoidance learning. Psychonomic Science, 1968, 11, 155.

WIMER, C. Magnesium pemoline: Effects on active and passive avoidance conditioning in mice. Psychonomic Science, 1968, 12, 23-24.

YEUDALL, L. T., ROYCE, J. R., \& De LEEUW, $M$. An automatic apparatus for avoidance-conditioning. Psychological Reports, $1968,22,139142$.

\title{
Cage activity in the California antelope ground squirrel
}

A. L. CONE and DONNA M. CONE, Lynchburg College, Lynchburg, Va. 24504

Cage activity of six California antelope ground squirrels was measured twice daily (moming and night) under six levels of ambient illumination (dark, less than 1.0, 2.5, 5.0, 25.0, 50.0 ft-c). Analysis of variance indicated that the Ss were significantly more active in the morning than at night under all levels of illumination. In addition, the Illumination by Time of Day interaction was significant. Increasing levels of illumination produced decreasing cage activity in the morning, but did not significantly affect cage activity at night. Results are discussed in comparison to earlier measures of cage activity with the nocturnal Virginia opossum.
Cone \& Cone (1968) have reported that the effects of ambient illumination on the cage activity of the opossum (Didelphis virginiana) are not independent of the phase of the organism's circadian cycle. As illumination was increased above a range of $2 \frac{1}{2}$ to $5 \mathrm{ft}-\mathrm{c}$, cage activity during the nighttime (10 p.m. to midnight) decreased, while cage activity during the daytime (10 a.m. to noon) increased. The authors interpreted these finding in terms of Bindra's hypothesis (1959) that the relationship between arousal level and performance is best described as an inverted U-shaped curve. They contended that nocturnal animals, such as the opossum, experience optimal arousal at night under low levels of illumination, and that increasing illumination during this peak nighttime arousal period produced an arousal level high enough to lower cage activity. On the other hand, increasing illumination during the relatively low arousal day time period produced an increase in arousal level sufficient to raise cage activity. In contrast to nocturnal animals, diurnal animals reach peak activity during the daytime (Marler \& Hamilton, 1966). Thus, optimal arousal in a diurnal animal would appear to be associated with daytime and intermediate levels of illumination. Increasing illumination during the peak day time arousal period in a diurnal animal should produce an arousal level high enough to lower cage activity, while the same increase in illumination at night should increase arousal sufficiently to raise cage activity. To test this hypothesis, the present replication of the opossum study was conducted using a diurnal rodent, the California an telope ground squirrel/Citellus leucurus leucurus).

\section{SUBJECTS}

The Ss were six adult ground squirrels, four males and two females, randomly selected from a colony of 12 animals. This colony had been obtained from the White Animal Farm in Maine and adapted to the laboratory for 2 weeks prior to the selection. The Ss were maintained on an ad lib diet of Purina rat chow and water throughout the experiment.

\section{APPARATUS}

Each S's living cage, a round wire-mesh enclosure 9 in. in diam and 9 in. high, was placed on a Lehigh Valley Electronics Company jiggle platform on top of a table in a sound-treated room. Each cage unit was separated from the other units by plywood partitions. The room was ventilated by an exhaust fan which also provided masking noise. The broad-band intensity of the noise was $82 \mathrm{~dB}$ as measured by a General Radio Sound Survey Meter; the low frequencies. contributed more than did the high frequencies to the overall noise level. The temperature of the test room was constantly monitored with a Bachrach Tempscribe and did not vary more than $4 \operatorname{deg} C$ during the experiment.

Eight inches above the wire-mesh top of each cage, a light-diffusing screen made of four layers of white tissue paper was placed. Six inches above the tissue paper, there was mounted a light socket into which bulbs of various wattages were inserted for the different levels of illumination. Levels of illumination were measured with a Weston Model 703 footcandle meter placed at the center of each cage. The six experimental levels of illumination were dark, less than 1 , $21 / 2,5,25$, and $50 \mathrm{ft}-\mathrm{c}$; the houselight was approximately $15 \mathrm{ft}-\mathrm{c}$.

Cage activity was automatically recorded on electromechanical counters from 10 p.m. 
to midnight and from 10 a.m. to noon. In addition, an Esterline-Angus Model A620X 20-channel event recorder provided continuous $24 \mathrm{~h}$ records of cage ac tivity. PROCEDURE

All Ss lived continuously in the test room. Each day between 2 and 2:30 p.m., food and water containers were topped up, and on every 6th day, a clean pan of sawdust was placed under each living cage. Except for the 4 test hours in each 24h period, the following illumination conditions were in force: From 6 a.m. to 6 p.m., approximately $15 \mathrm{ft}-\mathrm{c}$ of illumination was provided to each cage by a centrally mounted houselight; at 6 p.m., this light went off automatically and remained off until $6 \mathrm{a} . \mathrm{m}$. From 10 p.m. to midnight and from 10 a.m. to noon, this LD 12:12 condition was automatically replaced by the designated experimental ilumination level. The six experimental illumination levels were randomly assigned to a.m. and p.m. times with the exception that one 2 by 6 replication had to be completed before a given level of illumination could be repeated at a given time of day. Bulbs to provide the experimental illumination levels were inserted during the daily maintenance period. Three consecutive replications of the 2 by 6 design were run.

\section{RESULTS}

An analysis of variance was performed on data transformed $(\sqrt{x+1})$ according to the suggestion by Edwards (1960) for frequency data whose probable underlying distribution is Poisson. The analysis used was based on a model proposed by Walker \& Lev (1953) for factorial designs using Ss as their own controls.

The results of this analysis indicate that Illumination produced a highly significant effect on cage activity $(F=3.680$, $\mathrm{df}=5 / 185, \mathrm{p}<.01)$ as did Time of Day $(F=107.098, \mathrm{df}=1 / 185, \mathrm{p}<.001)$. These variables were found to interact significantly $(\mathrm{F}=2.761, \mathrm{df}=5 / 185, \quad \mathrm{p}<.05)$.

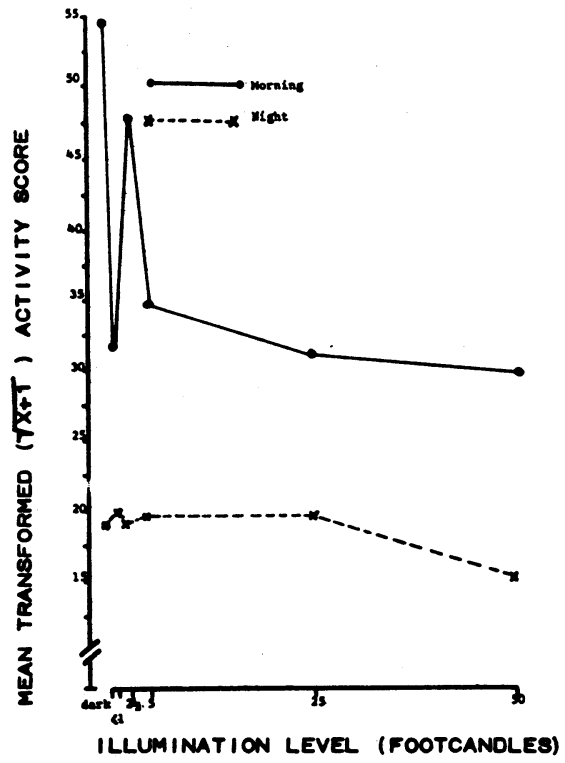

Fig. 1. Transformed activity scores as a function of level of illumination and time of day.

Examination of Fig. 1 shows that illumination had essentially no effect on cage activity at night. Furthermore, day time activity was much greater than nighttime activity under all illumination levels used. With the exception of the sharp drop in activity under the less than $1 \mathrm{ft}-\mathrm{c}$ condition, increasing illumination in daytime produced a smooth negatively accelerating decrease in cage activity. The Subjects variable used to remove effects of individual differences yielded a significant $F$ ratio $(F=2.305$, $\mathrm{df}=5 / 185, \mathrm{p}<.05$ ). However, when the scores of male Ss were contrasted with those of female Ss using the technique proposed by Scheffé (1953), no significant difference attributable to sex was found. DISCUSSION

In general, the results of the present study are congruent with those of the opossum study (Cone \& Cone, 1968). In both experiments, Illumination, Time of Day, and the Illumination by Time of Day interaction provided significant sources of variability. As would be expected, the diurnal ground squirrel was more active in the daytime, while the nocturnal opossum was more active at night. Only one-half of the hypothesized effect of increasing illumination was found in the present study, i.e., increasing illumiantion during the high-activity period (daytime) did produce a decrease in cage activity, but increasing illumination during the low-activity period (nighttime) did not increase cage activity. It should be noted that the increased activity produced by increasing illumination levels in the opossum study was far below that displayed under the optimal arousal conditions of night and dim illumination. Thus, it seems easier to drive activity down with increased illumination during a peak arousal period in an animal's circadian cycle than it is to raise activity with increased illumination during a low period in the animal's circadian cycle. Further experimentation is needed to determine whether this generalization can be extended to organisms which are less clearly noctumal or diurnal and to species born in captivity of domesticated parents.

\section{REFERENCES}

CONE, D. M., \& CONE, A. L. Cage activity in the Virginia opossum. Psychonomic Science, 1968, $10,259-260$.

BINDRA, D. Motivation: $A$ systematic reinterpretation. New York: Ronald Press, 1959.

EDWARDS, A. L. Experimental design in psychological research. (Rev. ed.) New York: Rinehart, 1960.

MARLER, P. R., \& HAMILTON III, W. J. Mechanisms of animal behavior. New York: Wiley, 1966.

SCHEFFÉ, H. A method for judging all contrasts in the analysis of variance. Biometrika, 1953, 40, 87-104. 